\title{
Radiolysis Gases from Nitric Acid Solutions Containing HSA and HAN (U)
}

by

J. R. Smith

Westinghouse Savannah River Company

Savannah River Site

Aiken, South Carolina 29808

DOE Contract No. DE-AC09-89SR18035

This paper was prepared in connection with work done under the above contract number with the U.S.

Department of Energy. By acceptance of this paper, the publisher and/or recipient acknowledges the U.S. Government's right to retain a nonexclusive, royalty-free license in and to any copyright covering this paper, along with the right to reproduce and to authorize others to reproduce all or part of the copyrighted paper. 
WSRC-TR-94-0525

Radiolysis Gases from Nitric Acid Solutions Containing HSA and HAN (U)

J.R. Smith

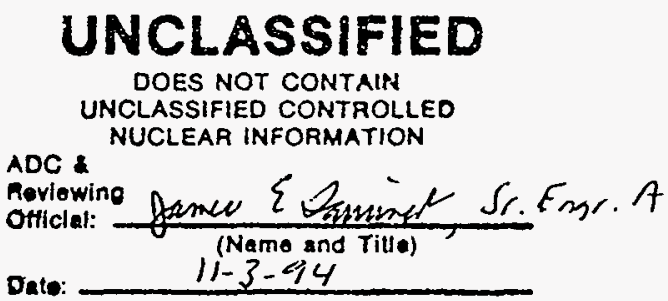

Westinghouse Savannah River Company Savannah River Site Aiken, SC 29808

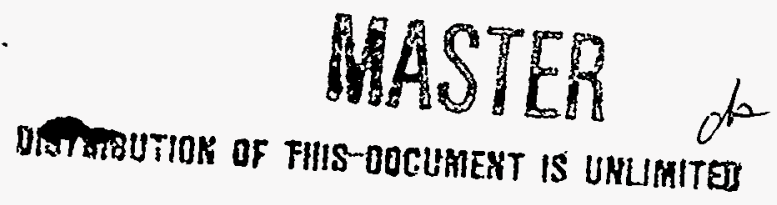




\section{DISCLAIMER}

This report was prepared as an account of work sponsored by an agency of the United States Government. Neither the United States Government nor any agency thereof, nor any of their employees, makes any warranty, express or implied, or assumes any legal liability or responsibility for the accuracy, completeness, or usefulness of any information, apparatus, product, or process disclosed, or represents that its use would not infringe privately owned rights. Reference herein to any specific commercial product, process, or service by trade name, trademark, manufacturer, or otherwise does not necessarily constitute or imply its endorsement, recommendation, or favoring by the United States Government or any agency thereof. The views and opinions of authors expressed herein do not necessarily state or reflect those of the United States Government or any agency thereof.

This report has been reproduced directly from the best available copy.

Available to DOE and DOE contractors from the Office of Scientific and Technical Information, P.O. Box 62, Oak Ridge, TN 37831; prices available from (615) 576-8401.

Available to the public from the National Technical Information Service, U.S. Department of Commerce, 5285 Port Royal Road, Springfield, VA 22161. 


\section{DISCLAIMER}

Portions of this document may be illegible in electronic image products. Images are produced from the best available original document. 
WSRC-TR-94-0525

Pg 1 of 25

Radiolysis Gases from Nitric acid Solutions Containing HSA and HAN (U)

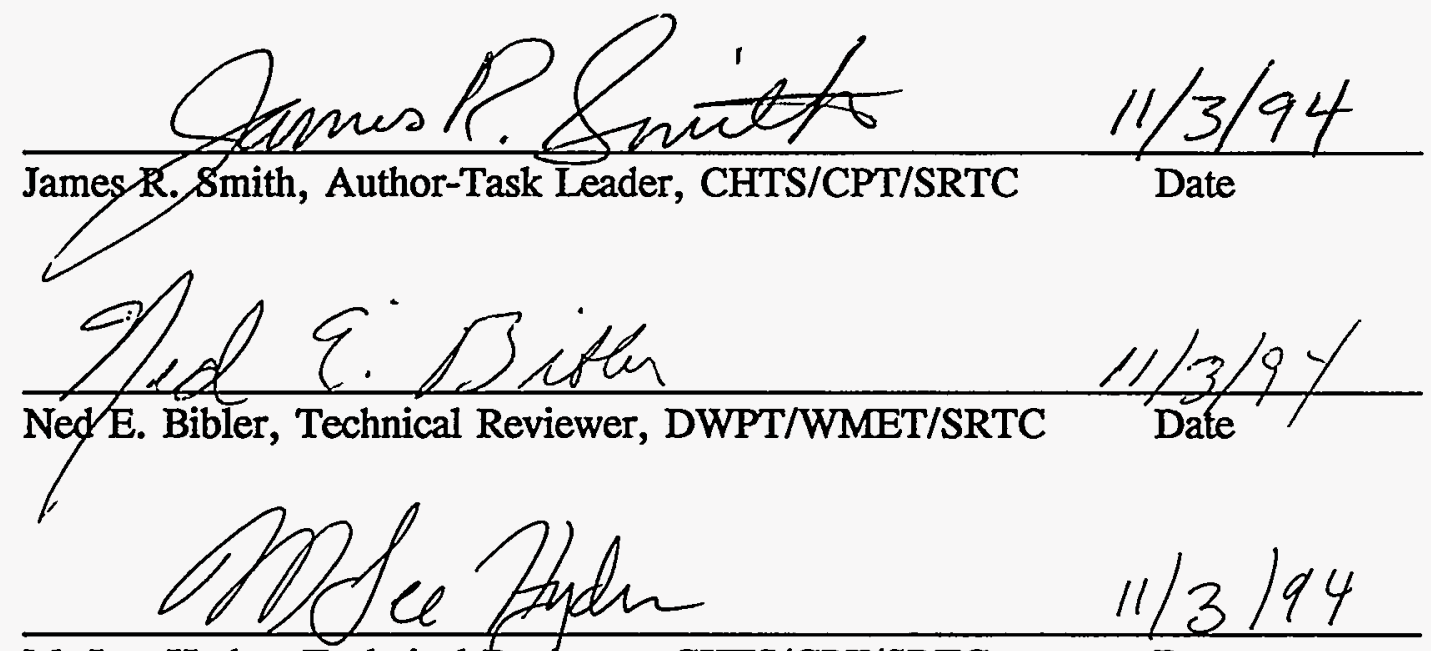

M. Lee Hyder, Technical Revjewer, CHTS/CPT/SRTC Date

October 28, 1994

Westinghouse Savannah River Company Savannah River Site Aiken, SC 29808 
WSRC-TR-94-0525

$\mathrm{Pg} 2$ of 25

\section{CONTENTS}

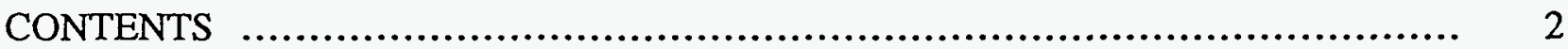

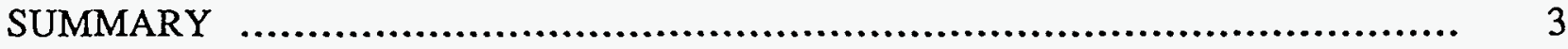

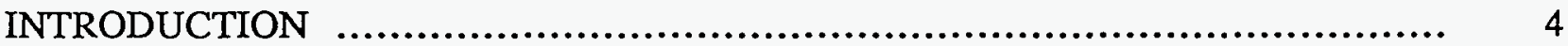

EXPERIMENTAL ....................................................................... 5

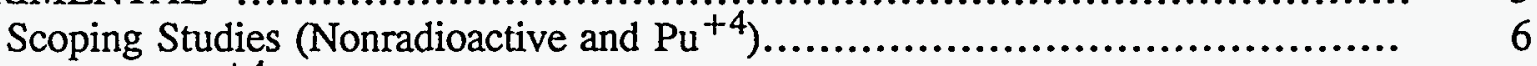

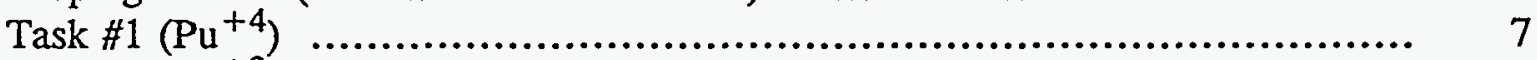

Task \#2 $\left(\mathrm{Pu}^{+3}\right)$...................................................................... 7

RESULTS AND DISCUSSION ....................................................... 8

$\mathrm{Pu}^{+4}$ Solutions (Scoping Study and Task \#1) ....................................... 9

$\mathrm{Pu}^{+3}$ Solutions (Task \#2) ............................................................ 11

Affect of Ascorbic Acid on Off-Gas Rate ....................................... 11

Hold Time for HSA in $\mathrm{Pu}^{+3}$ Solutions .......................................... 12

Off-gas Hydrogen Concentrations in $\mathrm{Pu}^{+3}$ Hold Tanks ............................ 12

Solution Chemistry Effect on Off-Gas Rate .................................... 14

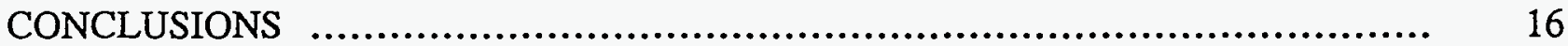

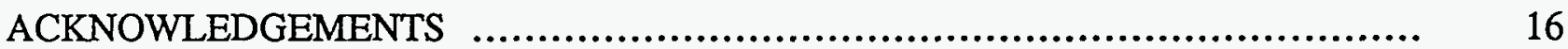

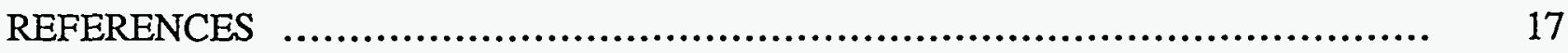

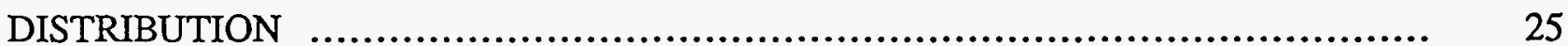

\section{TABLES}

Table 1 - Radiolysis Conditions Versus Time (Component Concentrations) $\quad$...... $\quad 8$

Table 2 - Linear Fits to Off-Gas Rate Versus Time Data ........................ 9

Table $3-\mathrm{Pu}^{+4}$ Solution Off-Gas Component Concentrations $\ldots . . . . . \ldots \ldots \ldots \ldots . . . . . \quad 10$

Table $4-\%\left[\mathrm{H}_{2}\right]$ in Off-Gas for $\mathrm{Pu}^{+3}$ Hold Tank Range of Conditions ............

Table 5 - Hold Time for HSA in $\mathrm{Pu}^{+3}$ Solutions ................................. 13

\section{FIGURES}

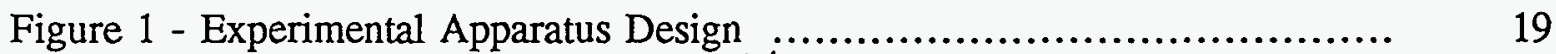

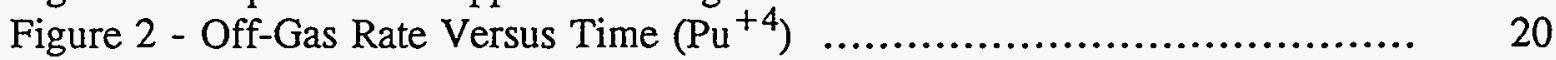

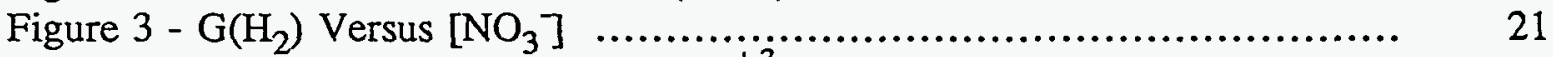

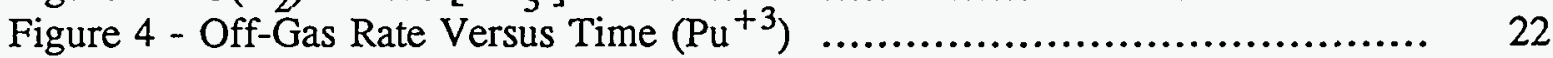

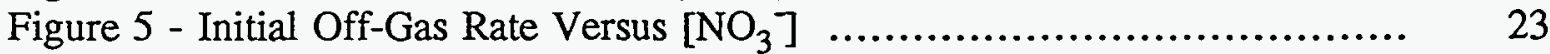

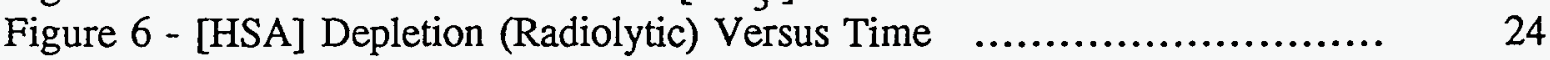


WSRC-TR-94-0525

Pg 3 of 25

\title{
Radiolysis Gases from Solutions Containing HSA and HAN (U)
}

\author{
by J. R. Smith \\ Westinghouse Savannah River Company \\ Savannah River Site \\ Aiken, SC 29808
}

SUMMARY

The concentration of hydrogen $\left(\mathrm{H}_{2}\right)$ in the radiolytically produced off-gas from 2.76-4.25M HNO 3 /Pu solutions has been found to be greatly reduced in the presence of sulfamic acid (HSA) and hydroxylamine nitrate (HAN). The $\mathrm{H}_{2}$ concentration $\left(\left[\mathrm{H}_{2}\right]\right)$ is reduced from 35 percent to about 4 percent by dilution caused from an increase in the production rates of nitrogen $\left(\mathrm{N}_{2}\right)$, nitrous oxide $\left(\mathrm{N}_{2} \mathrm{O}\right)$, and oxygen $\left(\mathrm{O}_{2}\right)$ gases. The generation rate of $\mathrm{H}_{2}$ was not affected by HSA or HAN giving a measured radiolytic yield, $\mathrm{G}\left(\mathrm{H}_{2}\right)$, value of 0.201 moleclues $/ 100 \mathrm{eV}$ for $2.765 \mathrm{M} \mathrm{NO}_{3}{ }^{-}$solution (a value of 0.213 is predicted from previous data). The $\mathrm{G}\left(\mathrm{H}_{2}\right)$ values are dependent on the solution nitrate concentration $\left(\left[\mathrm{NO}_{3}\right]\right)$. The generation rates of $\mathrm{N}_{2}, \mathrm{~N}_{2} \mathrm{O}$, and $\mathrm{O}_{2}$ are not dependent on the $\left[\mathrm{NO}_{3}\right]$ in this narrow range, but are dependent on the presence of HSA and the concentration of HAN.

The percentage $\left[\mathrm{H}_{2}\right]$ for the 2.5 to $3.0 \mathrm{M} \mathrm{NO}_{3}{ }^{-}$range expected in the offgas from the FB-Line $\mathrm{Pu}{ }^{+3}$ Hold Tanks is conservatively estimated to be about 3.5 to $4.5 \%$ for $\mathrm{Pu}^{+3}$ solutions initially containing 0.023M HAN/0.165M HSA. The upper limit $\left[\mathrm{H}_{2}\right]$ may actually be about $4.1 \%$ (4.3\% at $90 \%$ confidence limits) but more "initial" off-gas rate data is needed at about $2.9 \mathrm{M}\left[\mathrm{NO}_{3}\right]$ in $\mathrm{Pu}^{+3}$ solution for verification. Addition of ascorbic acid had no effect on the off-gas rate of $\mathrm{Pu}^{+3}$ solutions containing $\mathrm{HSA}$ and $\mathrm{NO}_{3}{ }^{-}$concentrations higher than those expected in the hold tanks.

The maximum "hold time" for 50 grams/liter $\mathrm{Pu}^{+3} / 0.165 \mathrm{M}$ HSA/0.023M HAN/2.5-3.0M $\mathrm{HNO}_{3}$ solution is $20.3 \pm 2.1$ days. After this time the HSA initially present will become exhausted and the $\left[\mathrm{H}_{2}\right]$ will increase to $35 \%$. This hold time may be longer in $\left[\mathrm{NO}_{3}\right]<3.0 \mathrm{M}$, but again more study is needed. 
WSRC-TR-94-0525

$\operatorname{Pg} 4$ of 25

\section{INTRODUCTION}

Bombardment of aqueous solutions by alpha (ionizing) radiation generates broken fragments, radicals and ions, of the water and chemicals in solution $1,2,3,4,5$. This process, called radiolysis, generates gases such as hydrogen and oxygen which are released as off-gas at a rate equal to their net production rate in solution. The generation rate of the various radiolysis products is proportional to the total dose of alpha energy imparted to the solution. The rate is usually defined in terms of the number of molecules produced per $100 \mathrm{eV}$ of alpha dose, denoted $\mathrm{G}\left(\mathrm{H}_{2}\right)$ for hydrogen gas.

Many chemicals and certain physical processes can have an effect on the $\mathrm{G}\left(\mathrm{H}_{2}\right)$ value. Nitrate has a very pronounced effect on the $\mathrm{G}\left(\mathrm{H}_{2}\right)$ value because of its' ability to scavenge aqueous electrons, $\mathrm{H}_{2} \mathrm{O}^{-}$, generated by radiolysis ${ }^{1,2,3,4,5,6}$

$$
\mathrm{H}_{2} \mathrm{O}^{-}+\mathrm{NO}_{3}^{-} \rightarrow \mathrm{NO}_{2}+2 \mathrm{OH}^{-}
$$

Aqueous electrons are precursors of hydrogen gas.

$$
2 \mathrm{H}_{2} \mathrm{O}^{-} \rightarrow \mathrm{H}_{2}+2 \mathrm{OH}^{-}
$$

As the nitrate concentration in solution increases the $\mathrm{G}\left(\mathrm{H}_{2}\right)$ value decreases ${ }^{2}$.

Nitrate may also have an effect in minimizing any acid, $\mathrm{H}^{+}$, dependence on radiolytic hydrogen formation. High acid concentrations could aid in the production of hydrogen by helping to form hydrogen atoms, $\mathrm{H}$; which can recombine or react with aqueous electrons to form hydrogen.

$$
\begin{aligned}
& \mathrm{H}^{+}+\mathrm{H}_{2} \mathrm{O}^{-} \rightarrow \mathrm{H} \cdot+\mathrm{H}_{2} \mathrm{O} \\
2 \mathrm{H} \cdot & \longrightarrow \mathrm{H}_{2} \text { and } \mathrm{H} \cdot+\mathrm{H}_{2} \mathrm{O}^{-} \rightarrow \mathrm{H}_{2}+\mathrm{OH}^{-}
\end{aligned}
$$

Hydrogen atoms react quicker than aqueous electrons with all species to form hydrogen gas ${ }^{6}$. They are also more stable with respect to oxidation by all oxidants, such as nitrate and hydroxyl ions, which could stop it from forming hydrogen gas. The reason hydrogen formation is independent of acid concentration is probably because alpha bombardment of nitrate produces species such as $\mathrm{NO}^{-}, \mathrm{NO}_{2}^{-}, \mathrm{O}^{-}$, and $\mathrm{O}_{2}^{-}$which may be able to absorb sufficient $\mathrm{H}^{+}$to effectively deplete it from the "recombination zone", approximated by the original alpha track of broken molecules ${ }^{6,7}$. There are many recombination reactions producing a variety of species. In $2.5 \mathrm{M} \mathrm{HNO}_{3}$ solution the main off-gases are hydrogen, $\mathrm{G}\left(\mathrm{H}_{2}\right)=.23$, and oxygen, $\mathrm{G}\left(\mathrm{O}_{2}\right)=.45$.

A physical process which has an effect on the $\mathrm{G}\left(\mathrm{H}_{2}\right)$ value is mechanical stirring ${ }^{2}$. This is because hydrogen is oxidized in solution by oxidants such as hydroxyl ions. Stirring degasses hydrogen from solution thus limiting its contact with these oxidants. The hydrogen off-gas rate, $\mathrm{G}\left(\mathrm{H}_{2}\right)$, is therefore increased with stirring.

The energy of a $5 \mathrm{MeV}$ alpha particle is imparted to the solution along a nearly linear path defined by a column approximately 100 angstroms wide ${ }^{7}$ and $0.0034 \mathrm{~cm}^{\text {long }}{ }^{8}(2.0 \mathrm{E}-8$ 
$\mathrm{cm}^{3}$ ). It is within this column that most of the fragments recombine. The literature points out that in nitric acid solutions of moderate strength as much as $90 \%$ of the radiolysis generated nitrite $\left(\mathrm{NO}_{2}\right)$ and hydrogen peroxide $\left(\mathrm{H}_{2} \mathrm{O}_{2}\right)$ recombine to reform nitric acid and water ${ }^{4}$. Using a $\mathrm{G}\left(\mathrm{H}_{2} \mathrm{O}_{2}\right)$ value of 1 , about 50,000 molecules will be produced in the column giving an initial concentration of $0.03 \mathrm{M}$. Scoping studies ${ }^{9}$ had shown that $\mathrm{H}_{2} \mathrm{O}_{2}$ reaction with $\mathrm{NO}_{2}^{-}$was about $25 \%$ faster than for $80 \%$ sulfamic acid (HSA) - 20\% hydroxylamine nitrate (HAN) solution in $2.5 \mathrm{M} \mathrm{HNO}_{3}$. Calculations predicted the HSA and HAN would effectively compete for nitrite in a solution $0.165 \mathrm{M} \mathrm{HSA} / 0.023 \mathrm{M} \mathrm{HAN} / 2.5 \mathrm{M} \mathrm{HNO}_{3}$ since these two compounds would be in much greater concentration than $\mathrm{H}_{2} \mathrm{O}_{2}$ in the recombination zone. Reaction of HSA and HAN with the radiolysis generated nitrite produces large amounts of $\mathrm{N}_{2}$ (nitrogen) and $\mathrm{N}_{2} \mathrm{O}$ (nitrous oxide) gases by the reactions

$$
\begin{aligned}
& \mathrm{HNO}_{2}+\mathrm{NH}_{2} \mathrm{SO}_{3} \mathrm{H} \rightarrow \mathrm{N}_{2}+\mathrm{H}_{2} \mathrm{SO}_{4}+\mathrm{H}_{2} \mathrm{O} \\
& \mathrm{HNO}_{2}+\mathrm{NH}_{3} \mathrm{OH}^{+} \rightarrow \mathrm{N}_{2} \mathrm{O}+2 \mathrm{H}_{2} \mathrm{O}+\mathrm{H}^{+}
\end{aligned}
$$

The $\mathrm{G}\left(\mathrm{O}_{2}\right)$ value also increases with HSA and HAN in solution since the unreacted $\mathrm{H}_{2} \mathrm{O}_{2}$ eventually decomposes to form $\mathrm{O}_{2}$ and water. The radiolysis hydrogen concentration in the offgas from nitric acid solutions containing HSA and HAN will therefore be much lower than the $35 \%$ normally seen, not because of a change in $\mathrm{G}\left(\mathrm{H}_{2}\right)$, but through dilution by released $\mathrm{N}_{2}$, $\mathrm{N}_{2} \mathrm{O}$, and $\mathrm{O}_{2}$ gases.

\section{EXPERIMENTAL}

A Scoping Study incorporating nonradioactive and radioactive experiments determined further work feasible. A Task Study ${ }^{10,11}$ was then performed guided by the earlier findings. The Task was divided into two portions, denoted Tasks $\# 1$ and $\# 2^{11}$, which were performed concurrently. The necessity for performing two sets of experiments was the relatively small amount of $\mathrm{Pu}^{+3}$ that could be produced and cleaned from a "column run" ${ }^{12}$, about 5 grams in $110 \mathrm{ml}$ solution. In a column run the $\mathrm{Pu}$ is reduced to the +3 state with ascorbic acid/HAN, absorbed onto a cation exchange resin, rinsed clean of contaminates, and then eluted to give concentrations of about 50 grams per liter. This small amount of $\mathrm{Pu}$ limited the total amount of radiolysis gases that could be generated per week. All column runs were performed, producing $\mathrm{Pu}^{+3}$ solutions, in Task \#2. Task \#1 used 20.59 grams of $\mathrm{Pu}^{+4}$ in $475 \mathrm{ml}$ of solution to generate the large amount of gas required, over $300 \mathrm{ml}$, to purge the gas sample tube sufficiently to obtain weekly gas samples for analysis. Task $\# 2$ was performed to compare the $\mathrm{Pu}^{+3}$ and $\mathrm{Pu}^{+4}$ off-gas generation rates. A correlation could then be made for the $\% \mathrm{H}_{2}$ concentration in the $\mathrm{Pu}^{+3}$ off-gas, assuming that the hydrogen production rate is unaffected by the $\mathrm{Pu}$ charge. Performing both was fortuitous in that differences were found to be associated with the charge of $\mathrm{Pu}$ and also with high $\left[\mathrm{HNO}_{3}\right]$. These findings will be discussed later. The experimentally generated data and calculations from this study are documented in a Calculation Note ${ }^{13}$. 
WSRC-TR-94-0525

$\mathrm{Pg} 6$ of 25

Scoping Study (Nonradioactive and $\mathrm{Pu}^{+4}$ Experiments)

Scoping Studies were performed to determine the feasibility of further work into the effects of HSA and HAN on reducing the hydrogen concentration in the off-gas of plutonium solutions. First a comparison of the relative reaction rates for nitrous acid reacting with $\mathrm{H}_{2} \mathrm{O}_{2}$ (hydrogen peroxide) and a combination of HSA and HAN was performed. As mentioned earlier nitrous acid was found to react $25 \%$ faster with $\mathrm{H}_{2} \mathrm{O}_{2}$ than with an equivalent combined concentration of HSA and HAN under the same conditions. Calculations revealed ${ }^{9}$ that the HSA and HAN might very possibly compete for the nitrite produced from nitrate radiolysis.

A decision was made to further investigate the effects of these compounds using $\mathrm{Pu}^{+4}$ in nitric acid solution at concentrations similar to those expected in the FB-Line $\mathrm{Pu}^{+3}$ hold tanks ${ }^{14}$. The experimental system (general design) used for all radioactive work is shown in Figure 1 (most resembles Task \#1 apparatus). An attempt was made to set the $\left[\mathrm{NO}_{3}\right]$ for the solution at the lower limit for the tanks, $2.5 \mathrm{M}$, to give a conservative $\% \mathrm{H}_{2}$ in the off-gas. The $\mathrm{G}\left(\mathrm{H}_{2}\right)$ value, molecules of $\mathrm{H}_{2}$ formed per $100 \mathrm{eV}$ of alpha dose, increases with decreasing $\left[\mathrm{NO}_{3}\right]^{2}$. The analysis of the solution used gave $2.38 \mathrm{M} \mathrm{NO}_{3}^{-}$. This conservatism was lost when the next four analyses of the "same" solution, during Task \#1, resulted in an average of $2.765 \pm .112 \mathrm{M}$ (Table 1). This didn't produce a problem since the $\mathrm{G}\left(\mathrm{H}_{2}\right)$ values are well known for $\left[\mathrm{NO}_{3}\right]$ from zero to $10 \mathrm{M}$ allowing extrapolation to the low nitrate concentration region ${ }^{2}$. The concentration of HSA and HAN was set at half that expected initially from processing to allow depletion of the HSA and HAN, and completion of the experiment, in only a few weeks.

During the scoping work much of the analytical methodology was developed. A technique for freezing the radiolytic and acidic decomposition of HSA during sampling was developed. The ability to analyze for HSA (sulfamate) by Ion Chromatography (IC) was tested and found satisfactory. A satisfactory analysis for HAN could not be found. Other techniques were also developed. A systematic error was found in total off-gas rate measurements when inverted burette readings were taken initially in the morning and final readings were taken in the afternoon (gave a high value). This was probably caused by changes in the ventilation system during the day. Taking readings over near 24 hour periods gave more consistent data and this technique was used for the Task studies.

The Scoping study ended with the depletion of the HSA and HAN, when the off-gas rate dropped to about a tenth of that observed earlier. The nitrite generated from radiolysis completely scavenged any remaining traces of these two reducing agents. The first gas analysis of the scoping study detected $\mathrm{N}_{2} \mathrm{O}$, which is a product of $\mathrm{HAN}$ reaction with $\mathrm{HNO}_{2}$ (nitrous acid). The second gas analysis observed very little $\mathrm{N}_{2} \mathrm{O}$. There was no observed change in the total off-gas rate observed; therefore it was assumed that the HAN acted in the same manner as the HSA. Since there was no analytical method for HAN, only HSA was added in Task \#1. Also the Scoping study had been performed with HAN present in the appropriate concentration. The only data generated during the Scoping Study that was used for calculation of results ${ }^{13}$ was the $[\mathrm{Pu}]$ data obtained at the beginning of the Scoping Study. This data was acquired with the same level of control as the data generated in the Task portions of this study and averaged, after a small correction for dilution, with the other [Pu] data obtained for Task \#1. 
WSRC-TR-94-0525

$\operatorname{Pg} 7$ of 25

Task \#1 $\left(\mathrm{Pu}^{+4}\right)$

The Task \#1 solution was generated by adding 4.029 grams of HSA (sulfamic acid) to the Scoping study solution. Sampling of the Task \#1 solution just after generation (and later samplings for nitrate) determined the initial solution to be $2.2 \mathrm{M} \mathrm{H}^{+} / 2.765 \mathrm{M} \mathrm{NO}_{3}^{-} / 0.1325 \mathrm{M}$ HSA/0.181M Pu. The time of addition of HSA defined time zero for the experimental data. The reaction system is shown in Figure 1. Once the system was sealed the radiolyticaly generated off-gases purged the gas space of the reaction bottle and the gas sample tube. The total amount of off-gas needed to adequately flush the gas space was about $300 \mathrm{ml}$ requiring about one week of gas generation per gas sample ${ }^{13}$. A total of three samples were transferred to the Shielded Cells (SRTC) area for gas chromatogram (GC) analysis. Adequate analysis for hydrogen was not obtained with the first sample. The GC was calibrated just prior to analysis ${ }^{10}$ to $\pm 2 \%$. The GC system measured the concentrations of hydrogen, oxygen, nitrous oxide, and carbon dioxide to a quoted precision of $\pm 10 \%$.

When the gas sample tube was removed for GC analysis solution samples were taken for analysis of nitrate, sulfamate, sulfate, and ammonium ion by Ion Chromatography (IC). In order to minimize removal of reaction solution, 100 lambda samples were taken and diluted into a known weight of deionized water ${ }^{13}$. This dilution was also used to freeze the radiolytic destruction of nitrate and sulfamate since the fraction of nitrite formed per unit of alpha dose is very small in dilute nitric acid solutions ${ }^{2,4}$. This dilution also essentially stopped the chemical hydrolysis of sulfamate since the hydrolysis rate is acid dependent ${ }^{15}$. Quadruplicate samples were taken to determine the error in sample preparation and in analysis by ADS on a given day (assuming the instrument is calibrated daily).

The production rate of radiolysis gases were measured using ar inverted burette (Figure 1). The temperature from day to day stayed fairly constant, $\pm 2{ }^{\circ} \mathrm{C}$, and averaged about $23^{\circ} \mathrm{C}$. The pressure at times changed rapidly with the passage of a weather front. Therefore atmospheric pressure readings were taken for the initial and final volume measurements and normalized to one atmosphere pressure ${ }^{13}$. A correction was also included for the reduction in pressure of the collected off-gas for the column height of the water above the water level in the beaker.

\section{Task \#2 $\left(\mathrm{Pu}^{+3}\right)$}

For Task $\# 2$ column runs, described earlier, were performed ${ }^{12}$ to produce solutions of $\mathrm{Pu}^{+3}$ containing $\mathrm{H}^{+}, \mathrm{NO}_{3}^{-}$, HSA, and $\mathrm{HAN}$ in concentrations similar to those expected in the $\mathrm{Pu}^{+3}$ Hold Tanks of FB-Line. The nitrate and HSA concentrations for these column runs was higher than the range expected for the $\mathrm{Pu}^{+3}$ hold tanks. This difference was probably due to a difference in the cuts to produce the "hearts" solution used ${ }^{16}$. The reaction solutions were sampled initially after production and at the end of study prior to depletion of the HSA. Sampling was performed as in Task \#1. 
WSRC-TR-94-0525

$\mathrm{Pg} 8$ of 25

The experimental apparatus used was similar to that shown in Figure 1 but used a 100 $\mathrm{ml}$ graduated cylinder fit with a ground glass joint $(120 \mathrm{ml}$ total volume $)$ as the reaction vessel and a $25 \mathrm{ml}$ titration burette (inverted) to catch and measure the off-gas. Off-gas volume measurements (rates) and data processing was performed in the same manner as in Task \#1. Because of the small amount of $\mathrm{Pu}$ that could be processed in each column run, gas sample analysis (GC) of the generated off-gas was not performed.

\section{RESULTS AND DISCUSSION}

The raw data from this work is tabulated and processed in a Calculation Note ${ }^{13}$. The reaction solution component concentrations are given in Table 1. The errors listed in this report are at the $90 \%$ confidence limit ${ }^{13}$, unless stated otherwise.

Table 1. Radiolysis Conditions Versus Time (Component Concentrations).

\begin{tabular}{|c|c|c|c|c|c|c|}
\hline Date & $\begin{array}{c}{\left[\mathrm{H}^{+}\right]} \\
\text {(Molar) }\end{array}$ & $\begin{array}{l}{\left[\mathrm{NO}_{3}{ }^{-}\right]} \\
\text {(Molar) }\end{array}$ & $\begin{array}{c}\text { [HSA] } \\
\text { (Molar) }\end{array}$ & $\begin{array}{l}{\left[\mathrm{SO}_{4}{ }^{-2}\right]} \\
\text { (Molar) }\end{array}$ & $\begin{array}{l}\text { [HAN] } \\
\text { (Molar) }\end{array}$ & $\begin{array}{c}\mathrm{Pu} \\
\text { (grams) }\end{array}$ \\
\hline \multicolumn{7}{|c|}{ Scoping Study } \\
\hline $11 / 17 / 93$ & $\sim 2.2$ & $\sim 2.38$ & $.0878 \pm .0004$ & $\sim 0$ & $.0122 \pm .0000$ & $20.59 \pm .47$ \\
\hline $12 / 10 / 93$ & $"$ & $2.38 \pm .36$ & $.0187 \pm .0028$ & $.0865 \pm .013$ & $\sim 0$ & " \\
\hline \multicolumn{7}{|l|}{ Task \#1 } \\
\hline $1 / 11 / 94$ & $2.2 \pm .14$ & $2.43 \pm .15$ & $.132 \pm .031$ & $.110 \pm .010$ & $\sim 0$ & $20.59 \pm .47$ \\
\hline $1 / 24 / 94$ & " & $2.85 \pm .27$ & $.0857 \pm .008$ & $.148 \pm .011$ & " & " \\
\hline $1 / 31 / 94$ & " & $2.74 \pm .20$ & $.0538 \pm .0044$ & $.147 \pm .021$ & " & " \\
\hline \multirow[t]{2}{*}{ 2/7/94 } & $"$ & $2.81 \pm .13$ & $.0320 \pm .0065$ & $.152 \pm .028$ & " & " \\
\hline & $3]$ average & $=2.77 \pm .11$ & & & & \\
\hline \multicolumn{7}{|c|}{ Task \#2 - Column Run \#1 } \\
\hline $\begin{array}{l}1 / 20 / 94 \\
\text { with Ascorbi }\end{array}$ & $\begin{array}{l}3.52 \pm .14 \\
\text { c acid }\end{array}$ & $4.086 \pm .057$ & $.315 \pm .008$ & $.0421 \pm .0012$ & $\sim .023$ & $5.80 \pm .17$ \\
\hline $2 / 7 / 94$ & 3] average & $\begin{aligned} & 4.29 \pm .19 \\
= & 4.25 \pm .17\end{aligned}$ & $.153 \pm .010$ & $.081 \pm .024$ & $\sim 0$ & $n$ \\
\hline \multicolumn{7}{|c|}{ Column Run $\# 2$} \\
\hline $2 / 15 / 94$ & $\begin{array}{l}.045 \pm .077 \\
3] \text { average }\end{array}$ & $\begin{aligned} & 3.35 \pm .21 \\
= & 3.75 \pm .16\end{aligned}$ & $\begin{array}{l}.254 \pm .007 \\
\text { all column run } \# 2\end{array}$ & $\begin{array}{l}.065 \pm .006 \\
\text { values averaged } t\end{array}$ & $\begin{array}{l}\sim .203 \\
\text { ogether) }\end{array}$ & $4.75 \pm .10$ \\
\hline \multicolumn{7}{|c|}{ Column Run $\# 2$, Attempted Dilution to $2.9 \mathrm{M} \mathrm{NO}_{3}^{-}$} \\
\hline 2/23/94 & $\sim 2.64$ & $3.45 \pm .23$ & $.231 \pm .011$ & $.0714 \pm .0061$ & .203 & $4.13 \pm .09$ \\
\hline 2nd Analysis & $"$ & $3.56 \pm .15$ & $.174 \pm .015$ & $.0636 \pm .0078$ & $"$ & $\pi$ \\
\hline \multirow{2}{*}{ 3/29/94 } & $n$ & $2.86 \pm .12$ & $.0523 \pm .0036$ & $.149 \pm .0063$ & $"$ & $"$ \\
\hline & 3] average & $=3.26 \pm .14$ & all column run $\# 2$ & values averaged & together) & \\
\hline
\end{tabular}


WSRC-TR-94-0525

Pg 9 of 25

$\underline{\mathrm{Pu}^{+4} \text { Solutions (Scoping Study and Task \#1) }}$

The off-gas rate data corrected to one atmosphere pressure and $23^{\circ} \mathrm{C}$ for the Scoping and Task \#1 studies is plotted versus time in Figure 2. The linear fit data to Figure 2 is given in Table 2. The plot of "HSA only" is the data from Task \#1. The data from the Scoping Study ("HSA and HAN") is higher due to the systematic error described earlier. Both sets of data point out that the off-gas rate is nearly linear and constant with time up to depletion of the sulfamic acid. Initially, during the first day, the off-gas rate is higher probably due to the reaction of HAN with either $\mathrm{Pu}^{+4}$ or nitric acid (or a combination). This idea was tested by adding HAN to a $\mathrm{Pu}^{+4}$ solution not containing HSA. The off-gas rate was initially very high, $39 \mathrm{ml} /$ day/gram at 0.44 days $^{13}$, but then quickly fell to zero. The dip below zero is attributed to the reaction of generated NO (now formed because of the lack of a reducing agent, HSA or HAN) with $\mathrm{O}_{2}$ to form $\mathrm{NO}_{2}$ which is quickly reabsorbed. Without HSA or HAN the total offgas rate is about an order of magnitude lower ${ }^{2,4}$ (and $35 \% \mathrm{H}_{2}$ ).

The off-gas component concentrations for the various gas samples analyzed are given in Table 3. The measured $\mathrm{H}_{2}$ concentration from the Scoping and Task Studies averages $3.57 \pm .10 \%{ }^{13}$ (statistically the same). There is a marked difference in oxygen concentration between the two studies. The presence of HAN in solution for the first gas sample in the

Table 2. Linear Fits to Off-Gas Rate Versus Time Data

\begin{tabular}{|c|c|c|c|c|c|}
\hline & $\begin{array}{l}\text { Plot } \\
\text { Description }\end{array}$ & Intercept & slope & $\begin{array}{c}\text { Rate at } \\
\text { (m1/g Pu/day) } \\
3.0 \text { days }\end{array}$ & $\begin{array}{l}\text { Rate at } \\
\text { (ml/g Pu/day) } \\
15.0 \text { days }\end{array}$ \\
\hline $\mathrm{Pu}^{+4}$ & HAN only & 36.922 & -27.873 & - & - \\
\hline $\begin{array}{l}\text { (Scoping \& } \\
\text { Task \#1) }\end{array}$ & $\begin{array}{l}\text { HSA only (without } \\
14.45 \text { day data) }\end{array}$ & 2.762 & $2.219 \mathrm{E}-3$ & - & 2.795 \\
\hline & HSA \& HAN & 3.278 & $5.901 \mathrm{E}-4$ & - & - \\
\hline \multicolumn{6}{|c|}{$\mathrm{Pu}^{+3}$ (Task \#2) } \\
\hline 0 - 4.5 days & $4.245 \mathrm{M} \mathrm{NO}_{3}^{-}$ & 2.294 & .0100 & 2.324 & - \\
\hline$"$ & $3.750 \mathrm{M} \mathrm{NO}_{3}^{-}$ & 2.366 & -.0267 & 2.286 & - \\
\hline$"$ & $3.255 \mathrm{M} \mathrm{NO}_{3}^{-}$ & 2.406 & .0294 & 2.494 & - \\
\hline $4.5-12$ days & $4.245 \mathrm{M} \mathrm{NO}_{3}^{-}$ & 2.179 & .0441 & - & - \\
\hline & $3.750 \mathrm{M} \mathrm{NO}_{3}^{-}$ & 2.088 & .0709 & - & - \\
\hline$"$ & $3.255 \mathrm{M} \mathrm{NO}_{3}^{-}$ & 2.546 & $7.98 \mathrm{E}-3$ & - & - \\
\hline over 12 days & $4.245 \mathrm{M} \mathrm{NO}_{3}^{-}$ & 2.822 & $-5.18 \mathrm{E}-3$ & - & 2.745 \\
\hline " & $3.255 \mathrm{M} \mathrm{NO}_{3}^{-}$ & 2.705 & $-2.80 \mathrm{E}-3$ & - & $\begin{aligned} & 2.663 \\
= & 2.73 \pm .11\end{aligned}$ \\
\hline
\end{tabular}


WSRC-TR-94-0525

$\operatorname{Pg} 10$ of 25

Table 3. $\mathrm{Pu}^{+4}$ Solution Off-Gas Component Concentrations ${ }^{17,18}$.

\begin{tabular}{|c|c|c|c|c|c|}
\hline \multirow{2}{*}{\multicolumn{6}{|c|}{$\frac{\text { date }}{\text { Scoping Study }} \frac{\mathrm{H}_{2} \%}{(\mathrm{HSA} \text { and HAN) }} \frac{\mathrm{O}_{2}}{\%}$}} \\
\hline & & & & & \\
\hline $11 / 22 / 93$ & 3.52 & 26.6 & 5.1 & 0.1 & 64.68 \\
\hline $12 / 2 / 93$ & 3.69 & 23.3 & 0.2 & 0.1 & 72.71 \\
\hline \multicolumn{6}{|c|}{ Task \#1 (HSA only) } \\
\hline $1 / 24 / 94$ & - & 42.1 & 0.1 & 0.05 & \\
\hline $1 / 31 / 94$ & 3.57 & 48.3 & 0.06 & 1.0 & 52.93 \\
\hline $\begin{array}{l}\text { 2/7/94 } \\
\quad \text { aver }\end{array}$ & $\begin{array}{l}3.51 \\
3.57 \pm\end{array}$ & 45.9 & 0.01 & 0.05 & 49.47 \\
\hline
\end{tabular}

Scoping Study, representing the first week, may account for this lower oxygen concentration (discussed later) but the second analysis shows no sign of $\mathrm{N}_{2} \mathrm{O}$ (from nitrite reaction with HAN) and is still low in oxygen. Interestingly, the total off-gas rate is about the same.

The normally tabulated value for the relative production rate of compounds from radiolysis is the $\mathrm{G}$ value, denoted $\mathrm{G}\left(\mathrm{H}_{2}\right)$ for $\mathrm{H}_{2}$, and represents the molecules produced per 100 $\mathrm{eV}$ of radiation dose (in this case alpha). $\mathrm{G}\left(\mathrm{H}_{2}\right)$ is given by

$$
\mathrm{G}\left(\mathrm{H}_{2}\right)=\frac{\left[\mathrm{H}_{2}\right](\mathrm{R}, \mathrm{ml} / \mathrm{gPu} \text {-day })(6.023 \mathrm{E} 23 \mathrm{~mol} . / \mathrm{mole})}{(1.207 \mathrm{E} 15 \mathrm{MeV} / \mathrm{gPu} \text { day })(1 \mathrm{E} 4100 \mathrm{eV} / \mathrm{MeV})\left(24,287 \mathrm{ml} / \mathrm{mole}, 1 \mathrm{~atm} \mathrm{\&} 23^{\circ} \mathrm{C}\right)}
$$

where $\left[\mathrm{H}_{2}\right]$ is the fractional concentration of hydrogen in the off-gas and $\mathrm{R}$ is the total off-gas production rate. The dose imparted to the solution per gram of Pu per day, $1.207 \mathrm{E} 15 \mathrm{MeV}^{19,20}$, is for weapons grade $\mathrm{Pu}$. The average off-gas rate, $\mathrm{R}$, for the $\mathrm{Pu}^{+3}$ and 4 data is $2.73 \pm .11$ $\mathrm{ml} / \mathrm{gPu}$ day (Table 2). The average $\left[\mathrm{H}_{2}\right]$ in the off-gas for the $\mathrm{Pu}^{+4}$ solutions is $3.57 \pm .10 \%$ (Table 3). This gives a $\mathrm{G}\left(\mathrm{H}_{2}\right)$ value of .201. the $\mathrm{G}$ values for oxygen and nitrogen can be determined by replacing $\left[\mathrm{H}_{2}\right]$ by the appropriate fractions for these two compounds.

There is considerable data for $\mathrm{G}\left(\mathrm{H}_{2}\right)$ values for "stirred" $\mathrm{Pu}^{+4}$ solutions over a large range of nitrate concentrations $\mathrm{s}^{2,4}$. The production rate of hydrogen from radiolysis, proportional to $\mathrm{G}\left(\mathrm{H}_{2}\right)$, is normally via aqueous electrons and therefore is related to the water concentration in solution. The $\left[\mathrm{H}_{2} \mathrm{O}\right]$ in nitrate (or $\mathrm{HNO}_{3}$ ) solution should therefore be inversely proportional to the $\left[\mathrm{NO}_{3}{ }^{-}\right]$. The $\mathrm{G}\left(\mathrm{H}_{2}\right)$ versus $\left[\mathrm{NO}_{3}\right]$ data, including the point from this work, is very well fit ${ }^{13}$ by the simple equation

$$
\mathrm{G}\left(\mathrm{H}_{2}\right)=1.217 /\left(1+1.702\left[\mathrm{NO}_{3}\right]\right)
$$

A total of 36 data points were used in this fit, Figure 3, giving a calculated error (90\% 
WSRC-TR-94-0525

$\mathrm{Pg} 11$ of 25

confidence limits ${ }^{13}$ ) of $\pm 3.26 \%$ over the full concentration range, 0 to $10 \mathrm{M} \mathrm{NO}_{3}{ }^{-}$. The value calculated for $\mathrm{G}\left(\mathrm{H}_{2}\right)$ using this equation for $2.765 \mathrm{M}$ nitrate is 0.213 making the value from this study $5.8 \%$ low.

\section{$\underline{\mathrm{Pu}^{+3} \text { Solutions (Task \#2) }}$}

The radiolysis conditions for the $\mathrm{Pu}^{+3}$ solutions (Task \#2) are shown in Table 1. The off-gas data are plotted in Figure 4. The line fits to the data, Table 2, extend to the data points included in the fit, note some overlap. There seems to be three distinct regions to the off-gas data versus time for these solutions (Figure 4). There is initially a relatively low off-gas rate region which is generally flat lasting about 4 days. Next there is a transition region lasting about 8 days in which the off-gas rate increases at a constant rate to a level similar to that of the $\mathrm{Pu}^{+4} / \mathrm{HSA}$ system. At the 15 day point the off-gas rate for the 4.245 and $3.255 \mathrm{M}$ nitrate solutions are 2.745 and $2.663 \mathrm{ml} / \mathrm{g}$ Puday respectively, Table 2 . The rate in $2.765 \mathrm{M}$ nitrate/ $/ \mathrm{Pu}^{+4}$ solution, 2.795, is within the statistical range of these two values. This shows that the total off-gas rate is very constant in $\mathrm{HSA} / \mathrm{Pu}^{+3}$ or ${ }^{4}$ solution from 2.765 to $4.245 \mathrm{M}$ nitrate concentration.

Since there wasn't an analytical test for HAN, the dependence on HAN was tested by adding hydroxylamine-sulfate $\left(\mathrm{NH}_{2} \mathrm{OH} \cdot \mathrm{H}_{2} \mathrm{SO}_{4}\right)$ into the $3.75 \mathrm{M}$ nitrate run (Figure 4) at about 7.5 days, after dilution to $3.255 \mathrm{M}$ nitrate. As can be seen from the graph the initial off-gas rate once again was reduced but not as far. An increase in the initial off-gas rate compared to the $4.245 \mathrm{M} \mathrm{NO}_{3}{ }^{-}$rate was not unexpected since autocatalytic reaction of HAN with nitric acid is sensitive to the nitric acid concentration in the 2.8 to $3.2 \mathrm{M}$ region ${ }^{22}$. The just referenced work has a plot of "Variation of rate of nitrous acid formation in the oxidation of hydroxylamine by nitric acid at $25^{\circ} \mathrm{C}$ " for $0.01 \mathrm{M} \mathrm{HNO}_{3}$, etc., from 2 to $8 \mathrm{M} \mathrm{HNO}_{3}$ which has an inverse plot very similar to Figure 5. Figure 5 is a plot the off-gas rates at day 3 in Figures 2 and 4 . If the generation of species such as HNO, by reaction of HAN and nitric acid (discussed later), are reducing the total off-gas rate this "HAN affect" may be lost at $\left[\mathrm{NO}_{3}\right]$ less than about $3.0 \mathrm{M}$ and therefore wouldn't be of concern for the conditions of the $\mathrm{Pu}^{+3}$ Hold Tanks. The $3.255 \mathrm{M} \mathrm{NO}_{3}{ }^{-}$ data was expected to be for $2.9 \mathrm{M} \mathrm{NO}_{3}^{-}$(this was the expected result from the dilution) and should have resolved this question. Data therefore still needs to be acquired at about $2.9 \mathrm{M}$ $\mathrm{NO}_{3}{ }^{-}$.

\section{Affect of Ascorbic Acid on Off-Gas Rate}

Ascorbic acid was added to the $4.245 \mathrm{M} \mathrm{NO}_{3}{ }^{-} / \mathrm{Pu}^{+3}$ solution generated from column run \#1 at the 18 day point, Figure 4 . The initial [ascorbic acid] was $0.060 \mathrm{M}$. The initial high value may have been due to mechanical vibrations, centrifuge operation, in the glovebox used for the study. Ultrasonic vibrations de-gas solutions in much the same manner as stirring. This would also account for the later low off-gas rates observed as the main product gases $\left(\mathrm{N}_{2}\right.$ and $\left.\mathrm{O}_{2}\right)$ established a new equilibrium. Since the average off-gas rate is close to that observed before the 
WSRC-TR-94-0525

$\operatorname{Pg} 12$ of 25

addition of ascorbic acid there is no significant effect.

\section{Off-Gas Hydrogen Concentrations in $\mathrm{Pu}^{+3}$ Hold Tanks}

The hydrogen concentration expected in the off-gas can be calculated from its generation rate, $\mathrm{G}\left(\mathrm{H}_{2}\right)$, and the total off-gas rate, $\mathrm{R}$. The equation is the same as described earlier, equation (7), with some rearrangement and multiplication.

$$
\% \mathrm{H}_{2}=\frac{\left(\mathrm{G}\left(\mathrm{H}_{2}\right), \mathrm{mol} . / 100 \mathrm{eV}\right)(48.67,100 \mathrm{eV} \cdot \mathrm{ml} / \mathrm{gPu} \text { day } \cdot \mathrm{mol} .)}{(\mathrm{R}, \mathrm{ml} / \mathrm{gPu} \text { day })}
$$

The error associated with the $\% \mathrm{H}_{2}$ values are due to the errors in the $\mathrm{G}\left(\mathrm{H}_{2}\right)$ and $\mathrm{R}$ values. The error determined for $\mathrm{G}\left(\mathrm{H}_{2}\right)$ is $3.26 \%$ ( $90 \%$ confidence limits) ${ }^{13}$. This value is produced from more than one study and therefore should be more confident than data from one source which could have an undetected systematic errors. The error associated with $\mathrm{R}$ is extracted from the variance in data determining this value. The $\% \mathrm{H}_{2}$ needs to be calculated at two different times. $\mathrm{R}$ changes with time from an initially low but constant value to a higher value after about two weeks. The data that most closely represents the "initial" off-gas rate for $\mathrm{Pu}^{+3}$ solutions in the nitrate range expected for the $\mathrm{Pu}^{+3}$ Hold Tank conditions is for 3.255 $\mathrm{M} \mathrm{NO}_{3}{ }^{-}$, Figure 4, giving an $R$ value of $2.510 \pm .029^{13}$. The value for $R$ after 2 weeks is determined at 15 days and is $2.73 \pm .11(4.1 \%)$, Table 2 . Since this value was determined from three different experiments (two different experimental systems) it includes errors associated with volume measurements, calculation of total grams $\mathrm{Pu}$ in solution, and burette readings. Since the "initial" rate $\mathrm{R}$ value does not include these other sources of error, this percentage error (4.1\%) is also used for the initial rate error making it $2.51 \pm .10$. The values for $R$ at the 15 day point show that once the HAN is depleted the total off-gas rate is independent of the Pu charge (at least +3 and 4) and the nitrate concentration. For initial $\mathrm{R}$ the $\% \mathrm{H}_{2}$ is ${ }^{13}$

$$
\% \mathrm{H}_{2}=(48.67)\left(\frac{\mathrm{G}\left(\mathrm{H}_{2}\right)}{\mathrm{R}}\right)=(48.67)\left(\frac{1.217 /\left(1+1.701\left[\mathrm{NO}_{3}\right]\right)}{2.51}\right) \pm 5.24 \%
$$

The 2 week value is obtained by replacing the 2.51 value with 2.73 . Calculations for $\% \mathrm{H}_{2}$ in the off-gas for varying $\left[\mathrm{NO}_{3}\right]$ and the upper $90 \%$ confidence value are given in Table 4 .

\section{"Hold Time" of HSA in $\mathrm{Pu}^{+3}$ Solutions}

The $\left[\mathrm{H}_{2}\right]$ in the off-gas is reduced to near $4 \%$ only until the HSA in solution is depleted. The rate at which the HSA is destroyed is determined mainly by the total alpha dose, proportional to grams $\mathrm{Pu}$, per unit volume of solution. A smaller contributing factor is 
Table 4. $\%\left[\mathrm{H}_{2}\right]$ in Off-Gas for $\mathrm{Pu}^{+3}$ Hold Tank Range of Conditions.

\begin{tabular}{|c|c|c|c|c|c|c|}
\hline $\begin{array}{l}{\left[\mathrm{HNO}_{3}\right]} \\
\text { initial }\end{array}$ & $\begin{array}{l}{\left[\mathrm{NO}_{3}\right]} \\
\text { Molar }\end{array}$ & $\begin{array}{c}\mathrm{G}\left(\mathrm{H}_{2}\right) \\
\text { Bibler } \\
\text { Savel'ev }\end{array}$ & $\begin{array}{r}\mathrm{H}_{2} \% \\
\text { initial } \\
\end{array}$ & $\begin{array}{c}\mathrm{H}_{2} \% \\
\text { initial }(90 \%)\end{array}$ & $\begin{array}{r}\mathrm{H}_{2} \% \\
2 \text { weeks } \\
\end{array}$ & $\begin{array}{c}\mathrm{H}_{2} \% \\
2 \text { weeks }(90 \%)\end{array}$ \\
\hline 2.50 & 2.523 & 0.230 & 4.460 & 4.693 & 4.094 & 4.308 \\
\hline 2.55 & 2.573 & 0.226 & 4.389 & 4.619 & 4.029 & 4.240 \\
\hline 2.60 & 2.623 & 0.223 & 4.321 & 4.547 & 3.967 & 4.174 \\
\hline 2.65 & 2.673 & 0.219 & 4.254 & 4.477 & 3.906 & 4.110 \\
\hline 2.70 & 2.723 & 0.216 & 4.190 & 4.409 & 3.847 & 4.048 \\
\hline 2.75 & 2.773 & 0.213 & 4.128 & 4.344 & 3.790 & 3.988 \\
\hline 2.80 & 2.823 & 0.210 & 4.067 & 4.280 & 3.734 & 3.929 \\
\hline 2.85 & 2.873 & 0.207 & 4.009 & 4.218 & 3.680 & 3.873 \\
\hline 2.90 & 2.923 & 0.204 & 3.951 & 4.158 & 3.628 & 3.817 \\
\hline 2.95 & 2.973 & 0.201 & 3.896 & 4.100 & 3.577 & 3.764 \\
\hline 3.00 & 3.023 & 0.198 & 3.842 & 4.043 & 3.527 & 3.712 \\
\hline
\end{tabular}

hydrolysis but the rate is comparatively low near room temperature and included in the experimentally determined loss rate. The [HSA] versus time for Task \#1 and both column runs of Task $\# 2$ are plotted in Figure 6 . The [Pu] varied from 35 to 51 grams liter of solution (not normalized for $[\mathrm{Pu}]$ in Figure 6). Note the very linear drop in [HSA] for the $\mathrm{Pu}^{+4}$ solution. This is expected since radiolysis production of nitrite should be the major mechanism for destruction of HSA. The calculated "hold time" for $0.165 \mathrm{M}$ HSA and 50 grams/liter $\mathrm{Pu}^{+3}$ is given in Table 5, data from Table 1. The hold time is given by

$$
\text { H.T. }=(\Delta \text { Time })(.165)[\mathrm{Pu}] /(\Delta[\mathrm{HSA}])(50 \mathrm{~g} / \mathrm{l} \mathrm{Pu})
$$

Table 5. Hold Time for HSA in $\mathrm{Pu}^{+3}$ Solutions.

Initial Sampling Time Sampling Time 0.00

0.00
17.95 days 33.87 days
[Pu] grams/liter 51.319 34.805
$\Delta$ [HSA $] \quad 50 \mathrm{~g} / 1 \mathrm{Pu}$ and .165M HSA

Molar Days to Depletion

$$
18.79
$$

21.81

average $=20.30$

std dev. $= \pm 2.14$ 
WSRC-TR-94-0525

$\mathrm{Pg} 14$ of 25

The value for the $\mathrm{Pu}^{+4}$ solution calculated in this manner is 38.4 days. The radiolytic generation rate of $\mathrm{HNO}_{2}, \mathrm{G}\left(\mathrm{HNO}_{2}\right)$, increases with nitrate concentration ${ }^{4}$ but this change must be small over the range of nitrate concentrations measured, 2.765 to $4.245 \mathrm{M}$, since the rate of off-gas production stays nearly constant. The shorter hold time observed for the $\mathrm{Pu}^{+3}$ solutions is probably due to HSA reaction with HAN oxidation species (discussed in the next section). The HAN added to the initial $\mathrm{Pu}^{+3}$ solution diluted to $3.26 \mathrm{M} \mathrm{NO}_{3}{ }^{-}$resulted in a [HAN] of $0.0236 \mathrm{M}$. The resulting hold time was 21.81 days. The [HAN] for the 18.79 day value is not known but resulted from column run \#1 and should have been in the range of $0.023 \mathrm{M}$. The value of 20.3 days gives a good estimate of the hold time for a $\mathrm{Pu}^{+3}$ solution initially $0.165 \mathrm{M}$ HSA/0.236M $\mathrm{HAN} / 2.5$ to $3.0 \mathrm{M} \mathrm{HNO}_{3}$.

\section{Solution Chemistry Effect on Off-Gas Rate}

The rate of nitrous acid formation should be related to the decrease in off-gas rate because nitrous acid is generated from $\mathrm{HNO}^{22,23,24}$. $\mathrm{HNO}$ can react with $\mathrm{O}_{2}$ in solution producing $\mathrm{HNO}_{3}$ directly, reducing the total off-gas rate and the dilution of $\left[\mathrm{H}_{2}\right]$. The formation and reaction of HNO varies according to the oxidants in solution and the nitric acid (nitrate) concentration. Below about $2.8 \mathrm{M}$ nitrate, the HAN should be mainly oxidized by $\mathrm{Pu}^{+4}$ (in $\mathrm{Pu}^{+4}$ solution) ${ }^{23}$ by reactions of the type.

$$
\left[\mathrm{PuOH} \cdot \mathrm{NH}_{2} \mathrm{OH}^{+3}\right] \rightarrow \mathrm{Pu}^{+3}+\mathrm{NH}_{2} \mathrm{O} \cdot+\mathrm{H}_{2} \mathrm{O}
$$

and

$$
\mathrm{NH}_{2} \mathrm{O} \cdot+\mathrm{Pu}^{+4} \longrightarrow \mathrm{Pu}^{+3}+\mathrm{HNO}+\mathrm{H}^{+}
$$

The HNO can be further oxidized to nitrous acid or nitric oxide ${ }^{22}$

$$
\begin{aligned}
& \mathrm{H}_{2} \mathrm{O}+2 \mathrm{Pu}^{+4}+\mathrm{HNO} \rightarrow \mathrm{HNO}_{2}+2 \mathrm{H}^{+} \\
& \mathrm{HNO}+\mathrm{Pu}^{+4} \rightarrow \mathrm{NO}+\mathrm{H}^{+}
\end{aligned}
$$

At nitric acid (nitrate) concentrations higher than $2.8 \mathrm{M}$, the oxidation by nitric acid will occur in much the same manner ${ }^{22}$. The nitrous acid generated is quickly reduced to $\mathrm{N}_{2}$ or $\mathrm{N}_{2} \mathrm{O}$ by the HSA or HAN in solution.

$$
\mathrm{HNO}_{2}+\mathrm{NH}_{2} \mathrm{SO}_{3} \mathrm{H} \rightarrow \mathrm{N}_{2}+\mathrm{H}_{2} \mathrm{SO}_{4}+\mathrm{H}_{2} \mathrm{O}
$$

and

$$
\mathrm{HNO}_{2}+\mathrm{NH}_{2} \mathrm{OH} \rightarrow \mathrm{N}_{2} \mathrm{O}+2 \mathrm{H}_{2} \mathrm{O}
$$

The NO produced in reaction (15) also contributes to the production of $\mathrm{N}_{2}$ and $\mathrm{N}_{2} \mathrm{O}$ by reduction of nitric acid to nitrite

$$
2 \mathrm{NO}+\mathrm{HNO}_{3}+\mathrm{H}_{2} \mathrm{O} \rightarrow 3 \mathrm{HNO}_{2}
$$

The rapid oxidation of HAN by $\mathrm{Pu}^{+4}$ and corresponding greatly increased off-gas rate are 
WSRC-TR-94-0525

$\mathrm{Pg} 15$ of 25

observed in Figure 2 at the beginning of the Scoping Study run, "HSA and HAN", and for the "HAN only" run. The oxidation is surmised to be by $\mathrm{Pu}^{+4}$ because there isn't an equivalent initial increase in the $\mathrm{Pu}^{+3}$ solutions, even at higher nitrate concentrations. The HSA and HAN, both strong reducing agents, are limiting the autocatalytic oxidation behavior of the nitrate (nitric acid) by keeping the concentration of nitrous acid low. Oxygen is abundant in the $\mathrm{Pu}^{+4}$ solutions from radiolysis (Table 3) and there isn't any reason for $\mathrm{a} \mathrm{Pu}^{+3}$ system to be any different. The reduced concentration of oxygen in the off-gas in the Scoping Study is probably due to formation of NO, via HNO, by traces of HAN. The oxygen enters the reaction by

$$
2 \mathrm{NO}+\mathrm{O}_{2} \longrightarrow 2 \mathrm{NO}_{2}
$$

then

$$
2 \mathrm{NO}_{2}+\mathrm{H}_{2} \mathrm{O} \rightarrow \mathrm{HNO}_{2} \text { and } \mathrm{HNO}_{3}
$$

Note how one molecule of $\mathrm{N}_{2}$ or $\mathrm{N}_{2} \mathrm{O}$ is formed, reaction (16) and (17), for each molecule of oxygen consumed. This is how the oxygen concentrations in the Scoping and Task \#1 Study can be different but the total off-gas be about the same.

The $\mathrm{Pu}^{+3}$ solutions are interesting because there is an initial decrease in the total off-gas rate in a nitric acid (nitrate) concentration range where oxidation by nitric acid should produce large quantities of nitrous acid ${ }^{22}$ according to the above equations. The lack of autocatalytic oxidation is once again due to the presence of HSA and HAN. $\mathrm{Pu}^{+3}$ is not an oxidizing agent. This should allow the build-up of HNO, as in reaction (13), but with nitric acid as oxidant. The initial reduction in total off-gas rate is probably due to the reaction of HNO with dissolved $\mathrm{O}_{2}{ }^{24}$

$$
\mathrm{HNO}+\mathrm{O}_{2} \rightarrow \mathrm{HNO}_{3}
$$

Not only does this remove oxygen from the off-gas but eliminates the possibility of production of $\mathrm{HNO}_{2}$ and subsequent production of $\mathrm{N}_{2}$ or $\mathrm{N}_{2} \mathrm{O}$. Also the potential off-gas via $\mathrm{HNO}$ can be cut in half by ${ }^{24}$.

$$
2 \mathrm{HNO} \rightarrow \mathrm{N}_{2} \mathrm{O} \text { and } \mathrm{H}_{2} \mathrm{O}
$$

This explains the reduction in off-gas rate until the HAN is destroyed in $\mathrm{Pu}^{+3}$ solutions.

The shorter hold time observed for $\mathrm{Pu}^{+3}$ as compared to $\mathrm{Pu}^{+4}$ solutions is probably due to $\mathrm{HSA}$ reaction with $\mathrm{HAN}$ oxidation species, especially $\mathrm{HNO}_{2}$. These reactions would potentially produce extra $\mathrm{N}_{2}$ off-gas, but this must not make-up for the $\mathrm{O}_{2}$ lost to HNO reaction. If this mechanism is correct this faster HSA destruction rate would end with the destruction of HAN and may not occur at $\left[\mathrm{NO}_{3}\right]$ less than about $2.9 \mathrm{M}$. It is therefore possible that in the $\left[\mathrm{NO}_{3}\right]$ range of the $\mathrm{Pu}^{+3}$ Hold Tanks the hold time may be closer to 38 days.

The change in oxidation rate of HAN with nitric acid (nitrate) in the 2.8 to $3.2 \mathrm{M}$ range is very steep ${ }^{22}$ and decreases with decreasing $\left[\mathrm{NO}_{3}\right]$. The $\mathrm{Pu}^{+4}$ value in Figure 5 represents an upper limit off-gas rate (no reaction of $\mathrm{HAN}$ with $\mathrm{HNO}_{3}$ ). A curve in Figure 5 following the $\mathrm{Pu}^{+3}$ values probably would reach this limit at a nitrate concentration higher than $2.8 \mathrm{M}^{22}$. Another data point needs to be obtained at this $\left[\mathrm{NO}_{3}\right]$ to verify this prediction. 
WSRC-TR-94-0525

Pg 16 of 25

\section{CONCLUSIONS}

The $\%\left[\mathrm{H}_{2}\right]$ in the 2.5 to $3.0 \mathrm{M} \mathrm{NO}_{3}{ }^{-}$range should be about 3.5 to $4.5 \%$, as shown in Table 5 , for $\mathrm{Pu}^{+3}$ solutions that initially contain $0.023 \mathrm{M}$ HAN/0.165M HSA. In $\mathrm{Pu}^{+3}$ solution, $\left[\mathrm{NO}_{3}\right]>3.0 \mathrm{M}$, nitric acid oxidation of HAN generates species that probably react with dissolved $\mathrm{O}_{2}$ to reduce the total off-gas rate. This lower off-gas rate reduces the dilution of radiolytically produced $\mathrm{H}_{2}$. The upper limit $\%\left[\mathrm{H}_{2}\right]$ may actually be about $4.1 \%(4.3 \%$ at $90 \%$ confidence limits) at $\left[\mathrm{NO}_{3}\right]<3.0 \mathrm{M}$ but more "initial" off-gas rate data is needed at about $2.9 \mathrm{M}$ $\mathrm{NO}_{3}{ }^{-}$for verification. Further work could also include measurement of the effect of urea on the total off-gas rate. Per unit of nitrous acid reacted, urea will produce $50 \%$ more gas than $\mathrm{HSA}$ or HAN. The products from reaction of urea with nitrous acid are $\mathrm{N}_{2}$ and $\mathrm{CO}_{2}$ (no residual sulfate).

HSA is consumed at a constant rate, mainly defined by the radiolytic generation of nitrous acid (nitrite), in $\mathrm{Pu}^{+4}$ solutions, and possibly also in $\mathrm{Pu}^{+3}$ solutions not containing $\mathrm{HAN}$ or with $\mathrm{HAN}$ but $\left[\mathrm{NO}_{3}\right]<3.0 \mathrm{M}$. Until the reactivity of $\mathrm{HAN}$ at $\left[\mathrm{NO}_{3}\right]<3.0 \mathrm{M}$ (in the presence of HSA) is better understood, the expected hold time for 50 grams/liter $\mathrm{Pu}^{+3} / 0.165 \mathrm{M}$ HSA$/ 0.023 \mathrm{M}$ HAN/2.5-3.0M $\mathrm{HNO}_{3}$ solution is $20.3 \pm 2.1$ days.

The $\mathrm{G}\left(\mathrm{H}_{2}\right)$ value determined in this work at $2.765 \mathrm{M} \mathrm{NO}_{3}{ }^{-}$is slightly less $(5.8 \%)$ than predicted from the fit to the published data, equation (8), but falls within expected error. The production rate of $\mathrm{H}_{2}, \mathrm{G}\left(\mathrm{H}_{2}\right)$, therefore seems to be unaffected by the presence of HSA and HAN. Addition of ascorbic acid had no measured effect on the off-gas rate of $\mathrm{Pu}^{+3}$ solutions containing HSA and nitrate concentrations higher than those expected in the hold tanks. This test of its effect should be conservative for the range of nitrate concentrations expected presently.

\section{ACKNOWLEDGEMENTS}

I would like to thank Darro Ferrara (DWPT/SRTC) and Dave Herman (DWPT/SRTC) for their support in gas sample analyses and Amy Ekechukwu (ADS/SRTC) for development and testing of a sulfamate analysis by Ion Chromatography (IC). I would also like to thank Kevin Kalbaugh (CHTS/SRTC) for his hands on (glovebox) support of this study and Ed Kyser (CHTS/SRTC) for his knowledge of cation exchange resin processing of Pu solutions. 
WSRC-TR-94-0525

Pg 17 of 25

\section{REFERENCES}

1) M.L. Hyder, J. Phys. Chem., 69, 1858, (1965).

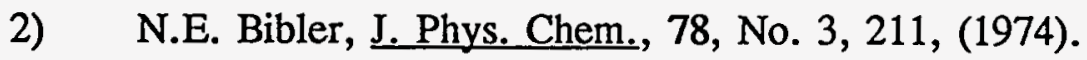

3) A.R. Kazanjian and D.R. Horrell, Radiation Effects, 13, 277, (1972).

4) Yu.I. Savel'ev, Z.V. Ershova, and M.V. Vladimirova, Radiokhimiya, 9, No. 2, 225 (1966).

5) J. C. Shephard, "Alpha Radiolysis of Plutonium (IV)-Nitric Acid Solutions", BNWL-751 UC-4 Chemistry, Pacific Northwest Laboratory, Richland WA, (1968).

6) G.B. Buxton, C.L. Greenstock, W.P. Helman, and A.B. Ross, "Critical Review of rate Constants for Reactions of Hydrated electrons, Hydrogen Atoms and Hydroxyl Radicals $\left(\mathrm{OH} / \mathrm{O}^{7}\right)$ in Aqueous Solution", Journal of Physical and Chemical Reference Data, American Chemical Society, Washington D.C. (1088).

7) J.W.T. Spinks and R.J. Woods, An Introduction to Radiation Chemistry, John Wiley and Sons, Inc., New York, NY, (1976) pp 59-61.

8) G. Friedlander, J.W. Kennedy, and J.M. Miller, Nuclear and Radiochemistry, 2nd Ed., pp 95, John Wiley and Sons, Inc., New York, NY, (1964).

9) J.R. Smith, "Hydrogen Generation in FB-Line Process Hold Tanks", CTS Weekly Report SRT-CTS-93-0271, Westinghouse Savannah River Site, Aiken, SC (1993).

10) J.R. Smith, "'Task Plan - Radiolytically Generated Hydrogen From Solutions Containing HSA and Ascorbic Acid (U)", WSRC-RP-93-1599, Savannah River Site, Aiken, SC 29808.

11) J.R. Smith, "QA Plan - Radiolytically Generated Hydrogen From Solutions Containing HSA and Ascorbic Acid (U)", WSRC-RP-93-1599, Savannah River Site, Aiken, SC 29808.

12) E.A. Kyser, "Cation Exchange Run CR-112", CHTS-Work Plan, SRTC, Westinghouse Savannah River Site, Aiken, SC (1994).

13) J.R. Smith, "Radiolysis Gases From Solutions Containing HSA and HAN (U)", Calculation Note X-CLC-F-00061, Savannah River Site, Aiken, SC 29808.

14) J.B. Schaade, "Hydrogen Generation Rates from Radiolysis in FB-Line Tanks (U)", 
WSRC TR-94-0525

$\operatorname{Pg} 18$ of 25

REFERENCES (continued)

NMP-EFB-93-0152, Calculation N-CLC-F-00001, Westinghouse Savannah River Site, Aiken, SC (1993).

15) D.G. Karraker, "Hydrolysis of Sulfamic Acid (U)", WSRC-TR-90-78, Westinghouse Savannah River Site, Aiken SC (1994).

16) Private communication with E.A. Kyser, SRTC.

17) D.T Herman, "Analysis of Gas Degradation Products from FB-Line", SRT-GTC-94-019, February (1994).

18) D.T Herman, "Analysis, for Oxygen, of Gas Degradation Products from FB-Line", SRTGTC-94-025, March (1994).

19) C.M. Lederer, J.M. Hollander, and I. Perlman, Table of Isotopes, 6th Ed., John Wiley and Sons, Inc., New York, NY, (1967).

20) W.F. Weston, "Plutonium Metal Feed Specification for Use in the Weapon Program Rocky Flats Plant", Vol. 1, Rev. A, US Government Memorandum, D.O.E., Albuquerque Operations Office (1985).

21) Jandel Scientific, SigmaPlot-Scientific Graphing Software (Windows), Version 1.01, Copyright 1985-1993, Jandel Corporation.

22) J.R. Pembridge and G. Stedman, Chem. Soc. J., Dalton Transactions, 1657 (1979).

23) G.S. Barney, "The Kinetics and Mechanism of Pu(IV) Reduction By Hydroxylamine", Atlantic Richfield Hanford Company, Richland, Washington (1971).

24) H.J. Emeleus and A.G. Sharpe, Advances in Inorganic Chemistry and Radiochemistry, Academic Press, New York 
WSRC-TR-94-0525

$\mathrm{Pg} 19$ of 25

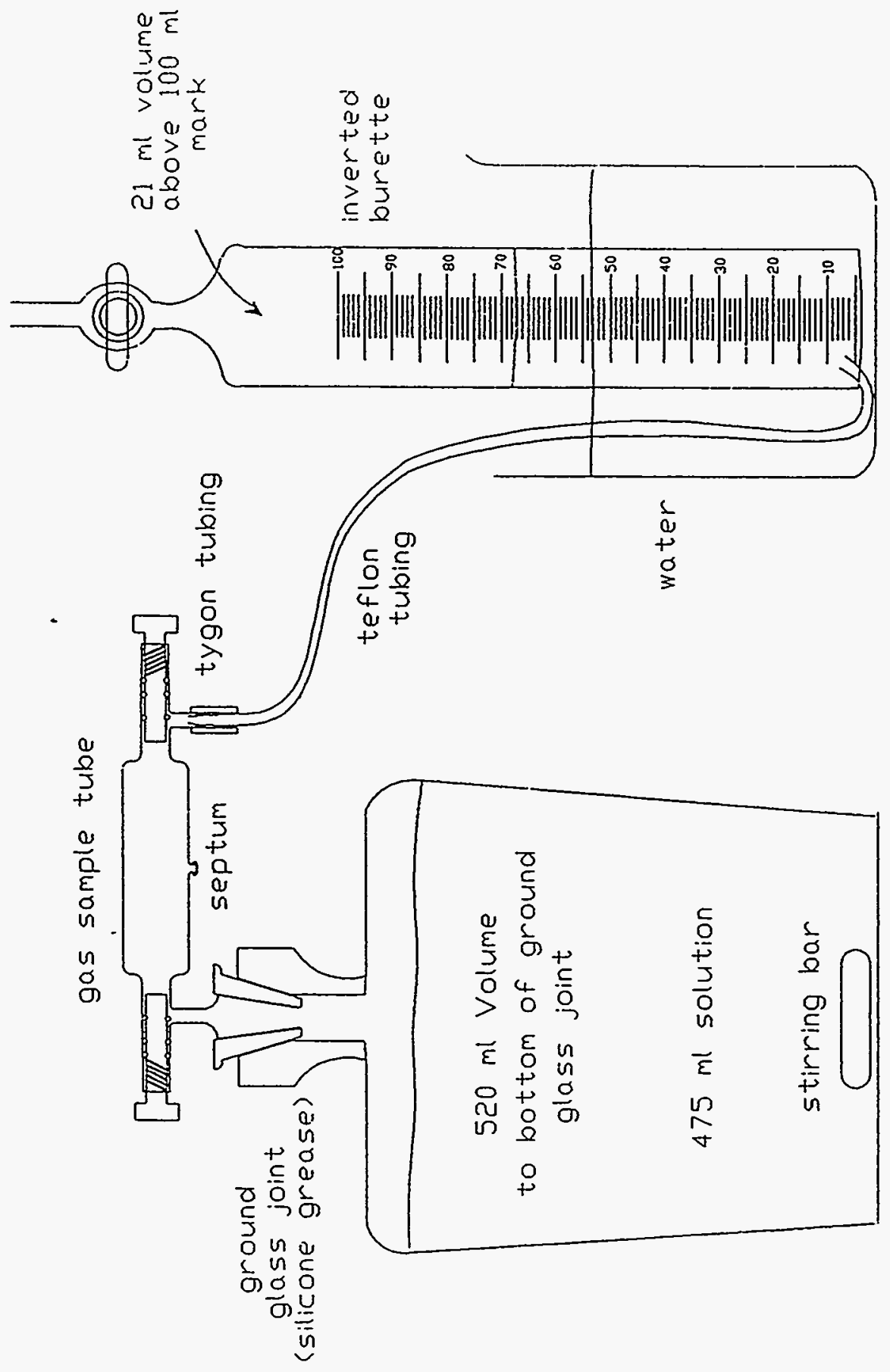

Figure 1. Experimental Apparatus Design. 
WSRC-TR-94-0525

Pg 20 of 25

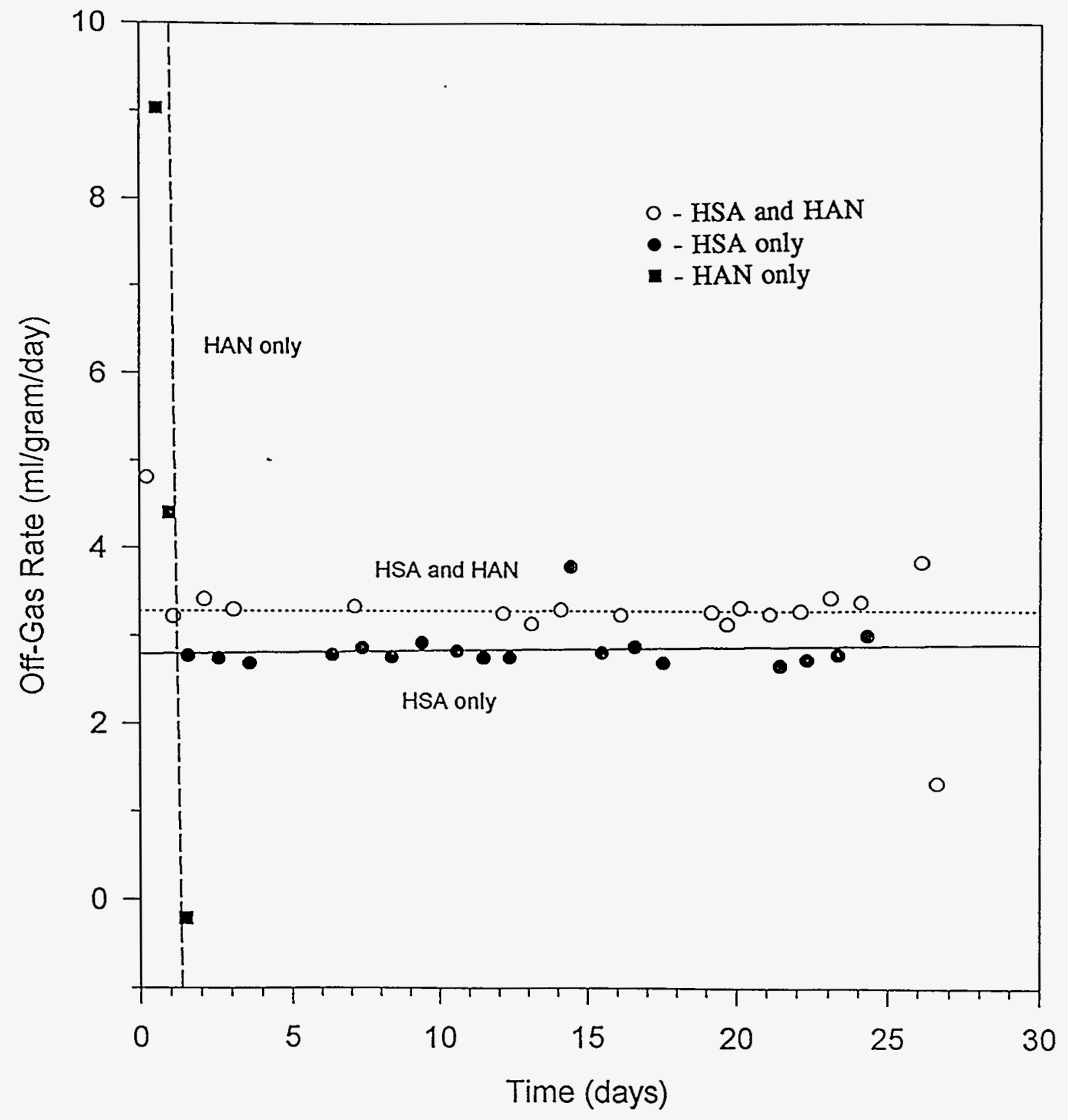

Figure 2. Off-Gas rate Versus Time (2.765 $\left.\mathrm{M} \mathrm{NO}_{3}{ }^{-} / \mathrm{Pu}^{+4}\right)$. 
WSRC-TR-94-0525

$\mathrm{Pg} 21$ of 25

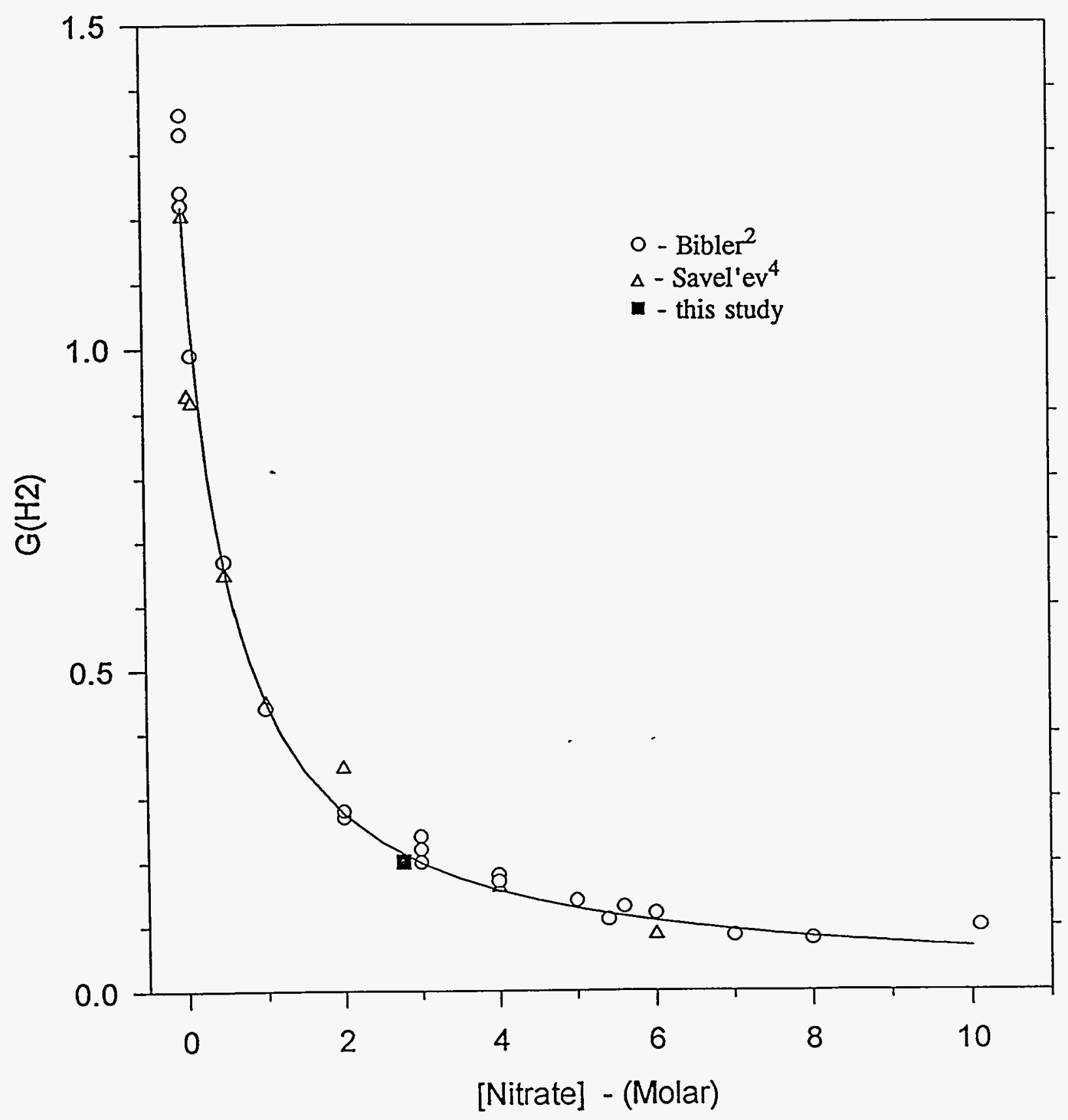

Figure 3. $\mathrm{G}\left(\mathrm{H}_{2}\right)$ Versus $\left[\mathrm{NO}_{3}\right]$. 
WSRC-TR-94-0525

$\operatorname{Pg} 22$ of 25

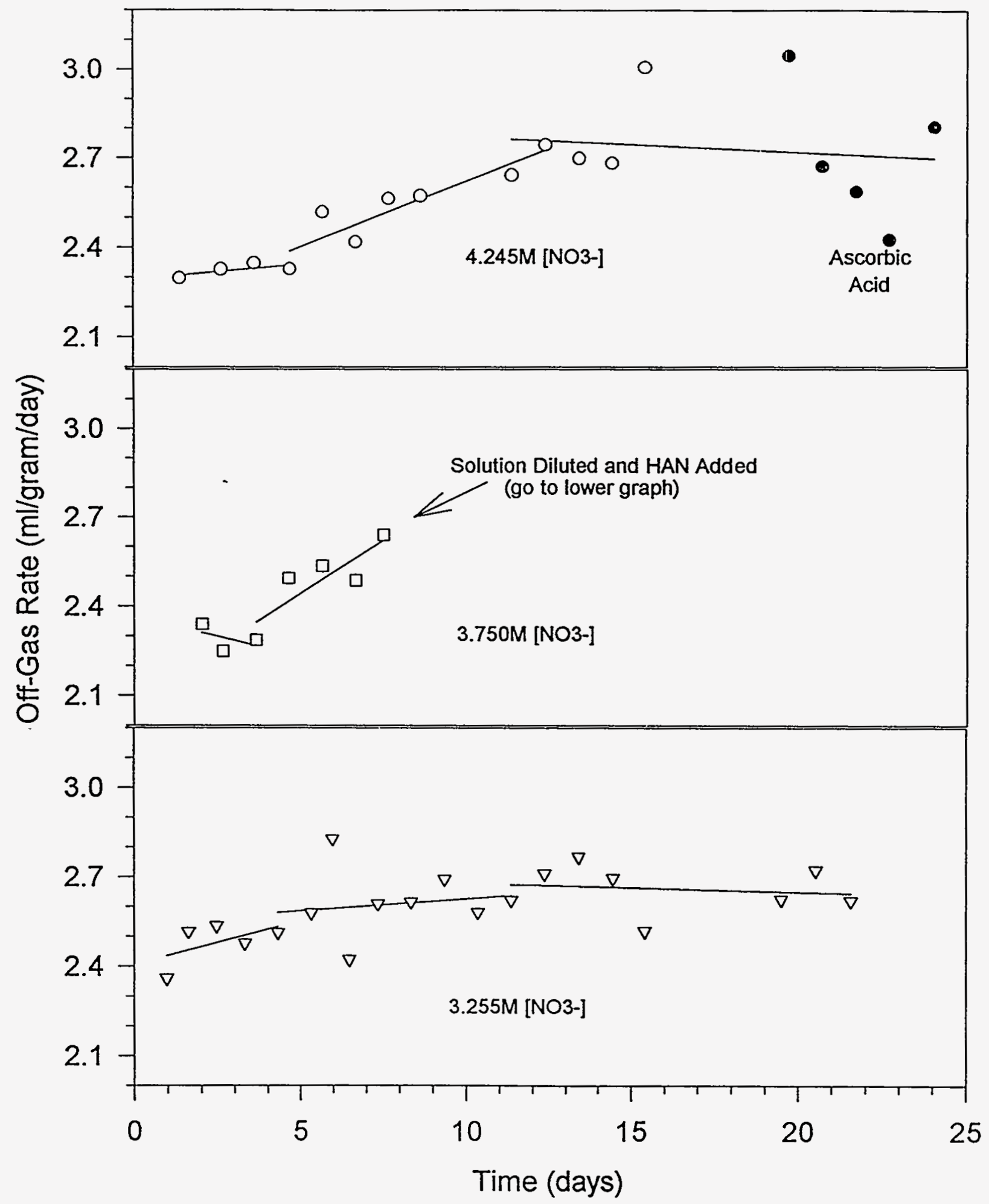

Figure 4. Off-Gas Rate Versus Time $\left(\mathrm{Pu}^{+3}\right)$. 


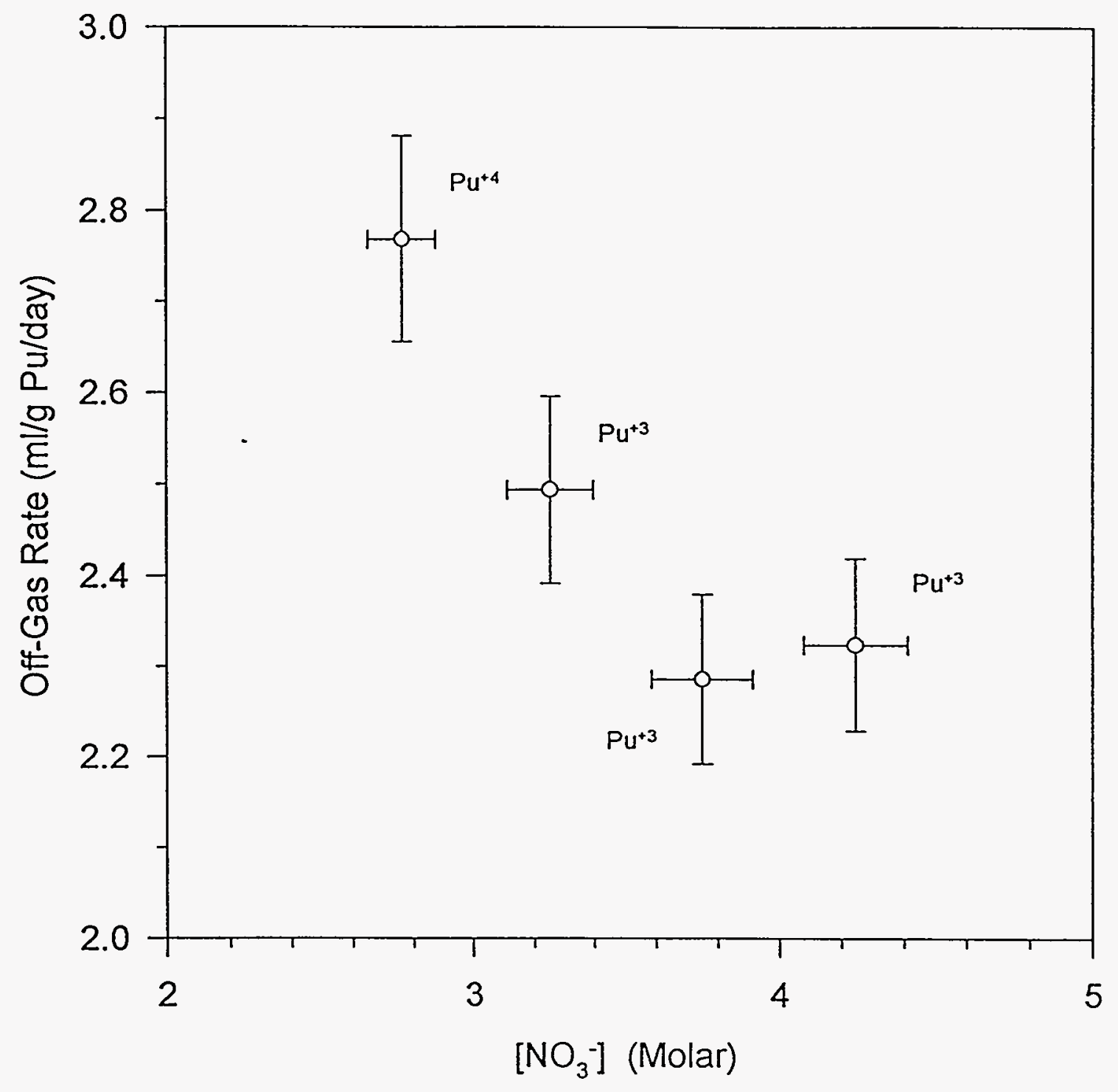

Figure 5. Initial Off-Gas Rate Versus $\left[\mathrm{NO}_{3}\right]$. 
WSRC-TR-94-0525

$\mathrm{Pg} 24$ of 25

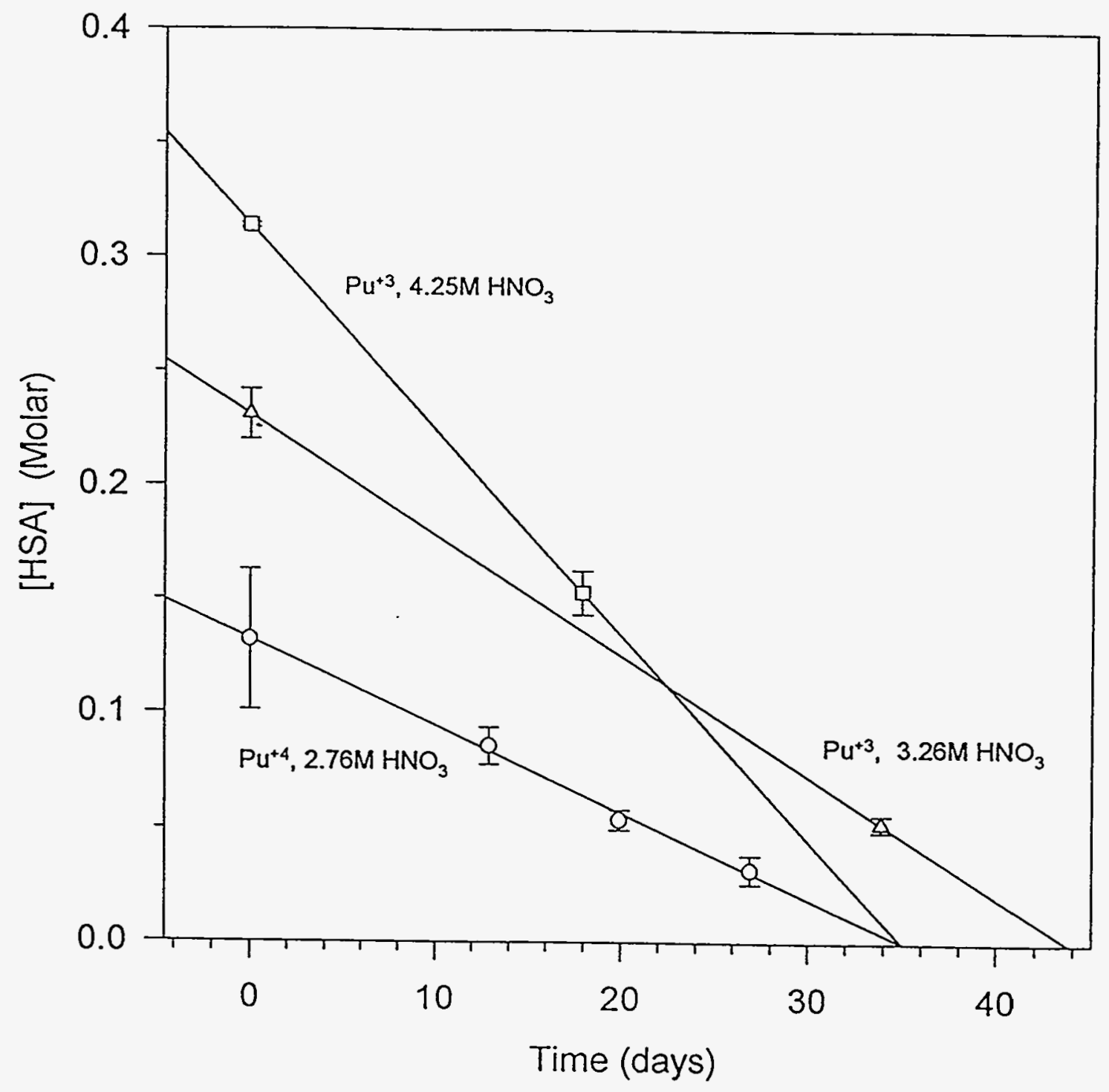

Figure 6. [HSA] Depletion (Radiolytic) Versus Time. 